\title{
Ornamental Ficus Diseases: Identification and Control in Commercial Greenhouse Operations ${ }^{1}$
}

\author{
D. J. Norman and Shad $\mathrm{Ali}^{2}$
}

\section{Introduction}

While edible figs (Ficus carica) are grown agronomically for delicious fruit, many Ficus species have been commercialized for decorative, ornamental purposes (Figure 1). These

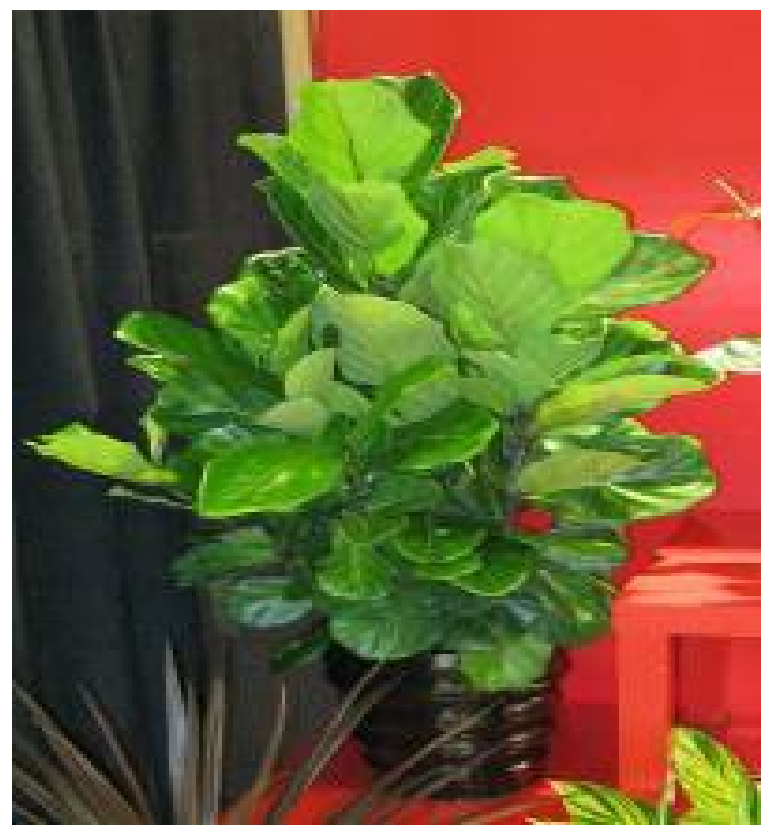

Figure 1. Fiddleleaf fig (Ficus lyrata) is an attractive ornamental indoor tree..

Credits: R. J. Henny horticultural Ficus varieties are used for interiorscape houseplant décor and for outdoor landscape design. This article provides guidelines for the identification and treatment of diseases that may be encountered during the commercial production of ornamental Ficus.

\section{Ficus}

The genus Ficus consists of more than 800 species, many of which are desirable foliage plants. Most ornamental Ficus are used as interior trees; however, a few are shrublike or grow as vines (Henley and Poole 1989). F. benjamina, the weeping fig, was first introduced to Florida's nursery industry during the late 1950s and has since become the most popular interior tree. F. elastica, the India rubber tree, was grown extensively during the early 1950s; however, today this variety is difficult to find because it has been replaced with newer cultivars. F. lyrata, known as fiddleleaf fig, has the largest leaf size among interiorscape Ficus. F. maclellandi 'Alii', sometimes called the Alii fig, is a relatively new introduction with long, narrow, willow-like leaves. 'Alii' is particularly well suited for medium-sized tree production. F. pumila (repens) is a popular vine often used for groundcover and topiary design in outdoor areas. It is cold tolerant to Zone 8. During the past 20 years, Florida nurserymen have listed more than 40 different species and

1. This document is PP308, one of a series of the Plant Pathology Department, UF/IFAS Extension. Original publication date August 2013. Visit the EDIS website at http://edis.ifas.ufl.edu.

2. D. J. Norman and Shad Ali, professors, Department of Plant Pathology, UF/IFAS Extension, Mid-Florida Research and Education Center, Apopka, FL 32703.

The use of trade names in this publication is solely for the purpose of providing specific information. UF/IFAS does not guarantee or warranty the products named, and references to them in this publication do not signify our approval to the exclusion of other products of suitable composition. All chemicals should be used in accordance with directions on the manufacturer's label. Use pesticides safely. Read and follow directions on the manufacturer's label. 
cultivars of Ficus for sale. These plants are sold in a wide range of container sizes for indoor and outdoor applications (Henley 1991).

\section{Production}

Ornamental Ficus propagation in Florida is achieved through three primary methods: layerage, cuttings, and tissue culture. Air layers are traditionally made on the stock plants of F. elastica cultivars, F. lyrata, and those cultivars of $F$. benjamina to be developed into very large trees. Ficus varieties to be grown into small trees, those grown as vines, and those to be used as shrubs are propagated by cuttings.

During the past several years, many growers, particularly those growing new varieties, have begun to use tissuecultured liners as the starting point for production. The liners from tissue culture produce very full, bushy plants because there are usually several upright stems per plug, each branching freely from the base.

Propagation via seed is used only occasionally with certain species or in breeding work to develop new varieties.

Most Ficus can be grown in full sun; the shrub and vine types of Ficus are usually grown in greenhouses or shadehouses with lower light levels. All Ficus for indoor use should be acclimatized under reduced light intensity. Because the range of plant form, growth habit, variety, container size, and usage application is so variable in this large genus, see Cultural Guidelines for Commercial Production of Interiorscape Ficus (http://edis.ifas.ufl.edu/ep136) for complete details about best cultural practices for producing a successful crop.

Plant disease at any stage during the propagation or production of Ficus can cause substantial economic losses if not quickly and properly identified and controlled. Three major bacterial diseases and seven fungal diseases are most often seen in Ficus production.

\section{Ficus Diseases Caused by Bacteria Crown Gall}

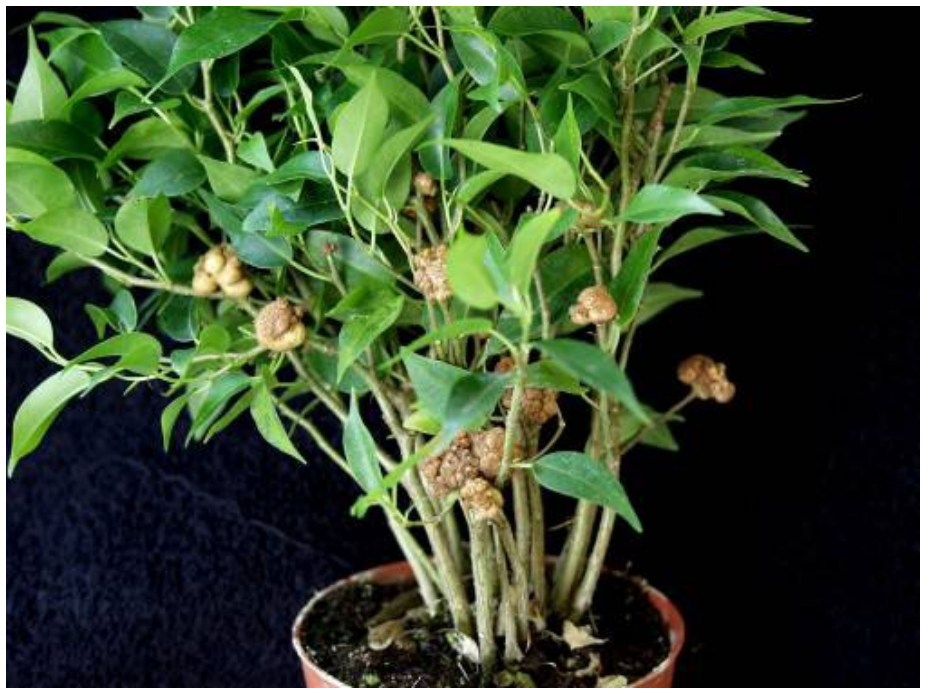

Figure 2. Crown gall on Ficus benjamina. Credits: D. J. Norman

Symptoms: Crown gall is characterized by the formation of galls that resemble tumors (Figure 2). Galls may form on the surface of stems or internally within stems, causing large, swollen sections. Galls can also form on roots. The first observable symptom is swelling of the plant tissue. This is usually associated with a wound; therefore, the initial swelling is often dismissed as normal callus formation. Within a matter of weeks after initial infection, this swelling takes on a spherical shape and becomes light green to tan in color. The gall then becomes irregular in shape and turns dark brown or black because of plant cells dying on the gall surface. As the gall enlarges, it crushes the xylem tissue and blocks water movement to the foliage.

\section{Causal agents: Agrobacterium tumefaciens}

Factors favoring the disease: Agrobacterium can live in the soil without a host for a number of years. Avoid contact with unsterilized native soil. Root-chewing insects can inflict wounds that can become infected.

Control: No known bactericides are effective against crown gall. A strict sanitation program is the best method of disease management. Obtain clean, disease-free stock plants. During propagation and pruning, cutting utensils should be sterilized between each cut. If pots and trays from contaminated plants must be reused, they should be scrubbed free of adhering soil, then soaked in a disinfectant to kill any remaining bacteria. When removing galls from plants, cuts should be made several inches below the gall tissue. 


\section{Pseudomonas Leaf Spot}

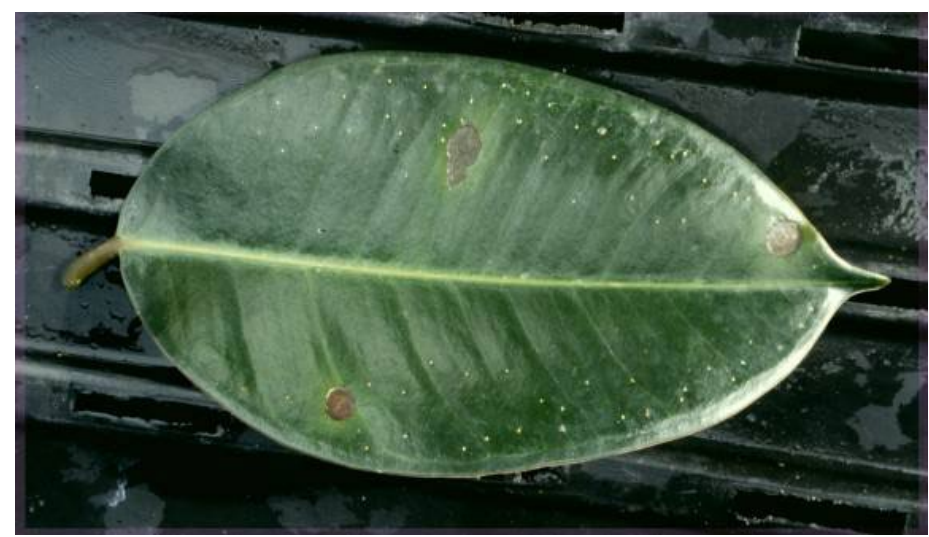

Figure 3. Pseudomonas leaf spot on Ficus elastica. Credits: D. J. Norman

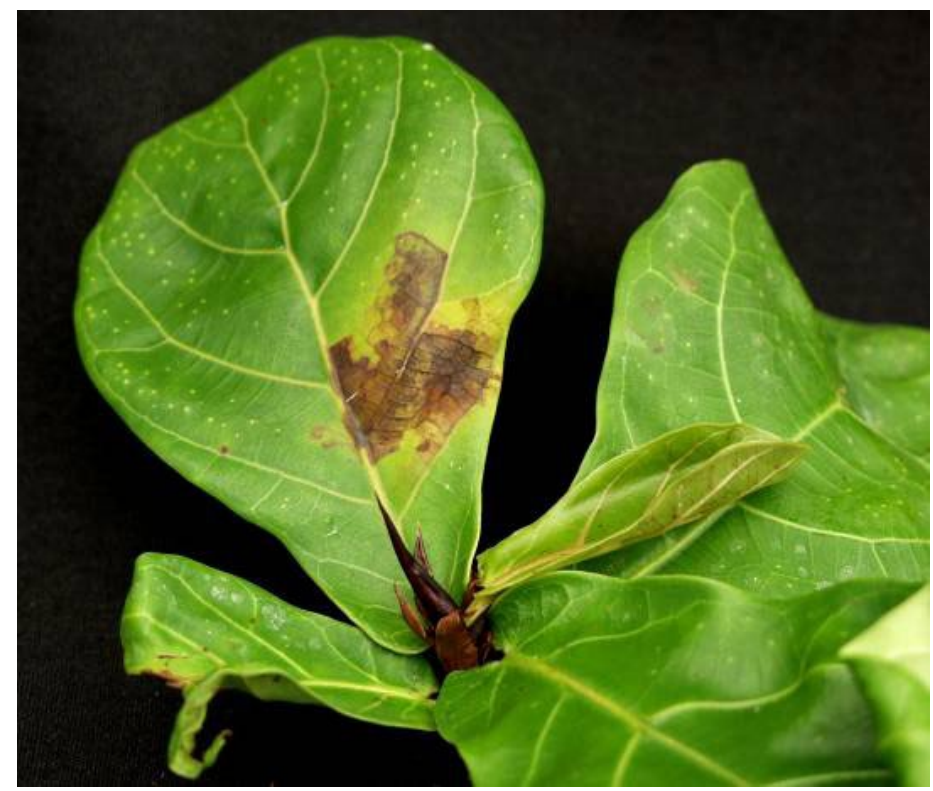

Figure 4. Pseudomonas leaf spot on Ficus lyrata.

Credits: D. J. Norman

Symptoms: This bacterial disease has many similarities to Xanthomonas leaf spot. Pseudomonas forms circular lesions on F. elastica (Figure 3) and angular lesions on many other Ficus species (Figure 4). These lesions are water soaked and randomly spaced on the leaves.

\section{Causal agent: Pseudomonas cichorii}

Factors favoring the disease: The warm temperatures and high humidity commonly seen during summer favor the pathogen.

Control and treatment: The first line of defense with this disease is exclusion; therefore, eliminate any plants showing disease. Minimize overhead watering since bacteria are easily splashed from plant to plant and can reinfect via stomatal openings. Minimize worker contact, especially if plants are wet.

Bactericides containing copper compounds (Kocide ${ }^{\circledast} 2000$, Cuprofix ${ }^{\oplus}$ ) or combinations of copper and mancozeb (Junction, Cuprofix $\mathrm{x}^{\oplus} \mathrm{MZ}$ ) can be used successfully to control this disease if used on a regular preventative basis.

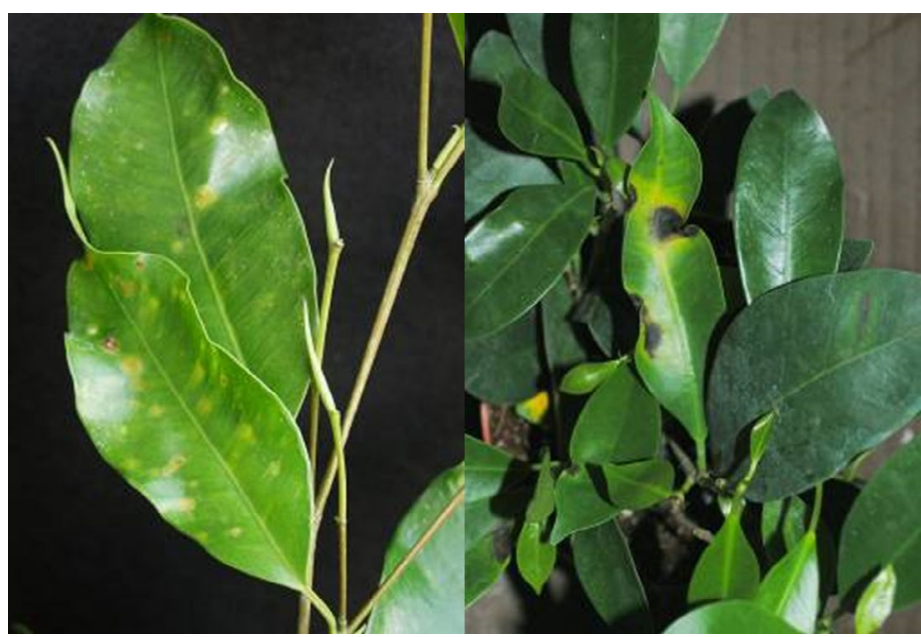

Figure 5. Xanthomonas leaf spot on Ficus benjamina and Ficus retusa. Credits: D. J. Norman

\section{Xanthomonas Leaf Spot}

Symptoms: Small, water-soaked, angular lesions appear on the leaves as the first sign of infection. These lesions become yellow (chlorotic) and eventually turn brown. When infections are severe, leaf drop may occur (Figure 5).

\section{Causal agent: Xanthomonas campestris}

Factors favoring the disease: Summer conditions with warmer temperatures and a wet, humid environment favor Xanthomonas development.

Control and treatment: Bactericides containing copper compounds (Kocide ${ }^{\circledast} 2000$, Cuprofix ${ }^{\circledast}$ ) or combinations of copper and mancozeb (Junction, Cuprofix ${ }^{\oplus} \mathrm{MZ}$ ) can be used successfully to control this disease if used on a regular preventative basis.

Minimize overhead watering. Infected lesions exude bacteria that are easily splashed from plant to plant. These bacteria gain access into Ficus leaves via stomatal openings.

Minimize worker handling of plants. Bacteria exuded onto leaves can easily be moved between plants by workers, especially if plants are wet. 
Eliminate diseased stock plants. The first line of defense with this disease is exclusion, which can best be achieved if stock plants are disease free.

\section{Ficus Diseases Caused by Fungi Anthracnose}

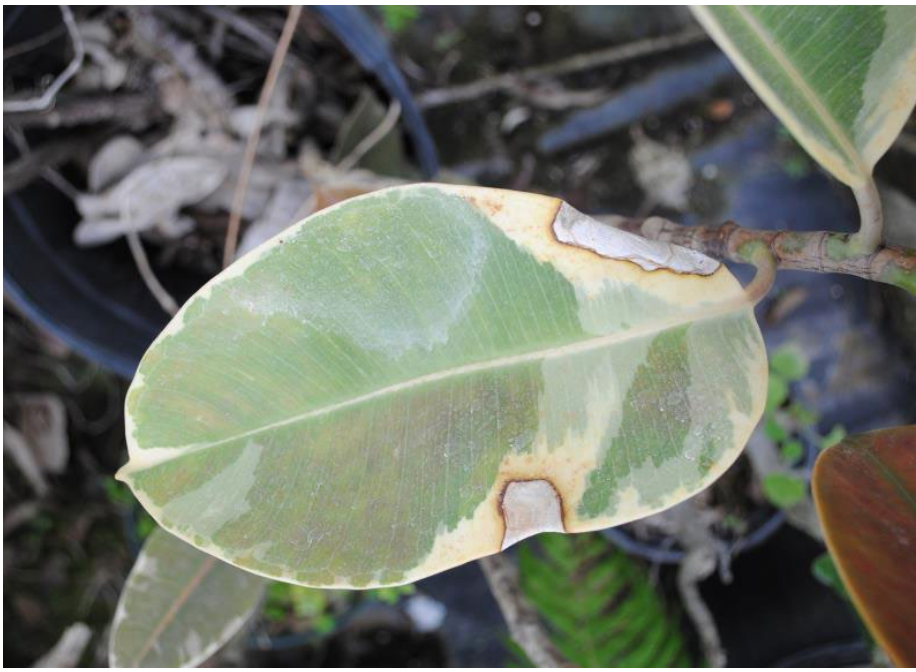

Figure 6. Anthracnose symptoms on Ficus elastica.

Credits: D. J. Norman

Symptoms: Anthracnose is characterized by necrotic spots on the leaf surface. Under humid conditions, brown masses of spores can form into concentric rings. Necrotic spots eventually become dark brown, and the leaves may fall off. Variegated cultivars of $F$. elastica are commonly infected with this pathogen (Figure 6). The white portion of the leaves lacking chlorophyll is weak and very susceptible. Anthracnose can also cause tip dieback on F. benjamina trees planted in interiorscapes.

Causal agents: Glomerella cingulata, Colletotrichum spp.

Factors favoring the disease: The disease favors wet conditions when cuttings are rooted under mist and high humidity in the summer months. This disease frequently occurs after misuse of pesticides has caused tissue damage.

Control and treatment: Minimize overhead irrigation and exposure to rainfall.

A number of fungicides can effectively control anthracnose on Ficus (Protect DF, Dithane ${ }^{\oplus}$ - mancozeb; Chipco ${ }^{\circledR}$ 20619 - iprodione; Insignia ${ }^{\oplus}$ - pyraclostrobin; Heritage ${ }^{\oplus}$ - azoxystrobin).

\section{Botrytis Blight}

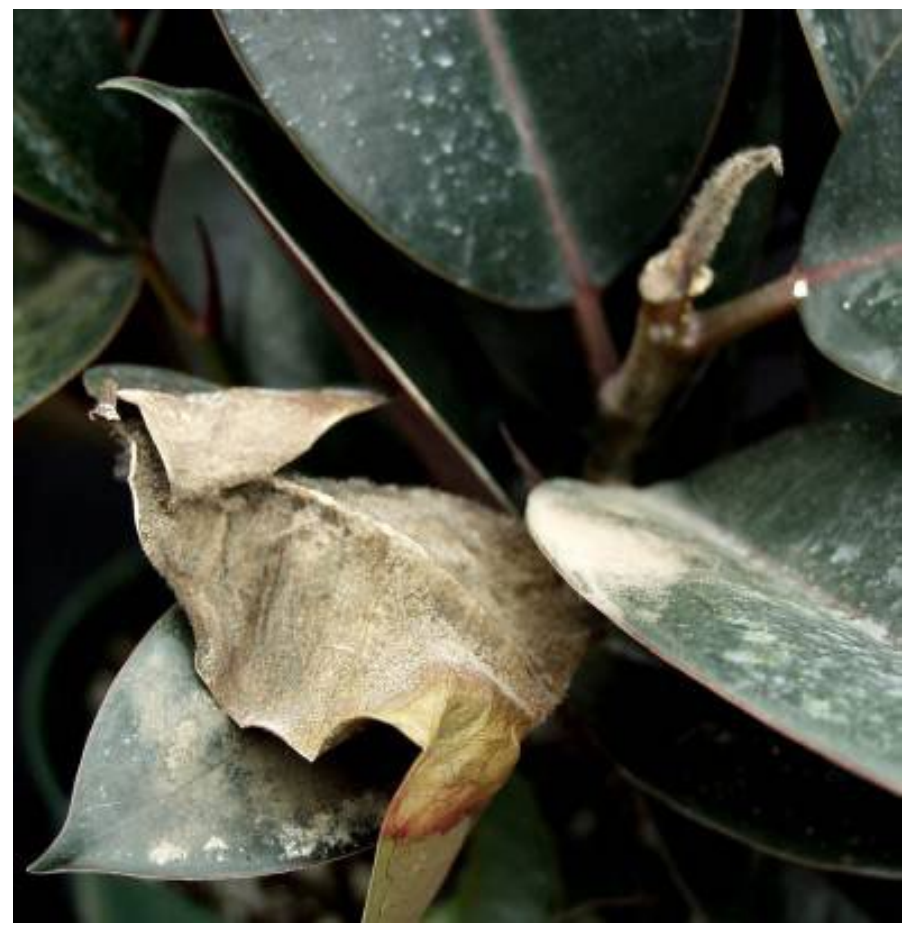

Figure 7. Botrytis blight on Ficus elastica. Note the fluffy spores. Credits: D. J. Norman

Symptoms: Young leaves and stems are first to be infected, turning brown to black, with brown fuzz (mycelia) developing on infected tissue. As the disease progresses, large sections of foliage collapse and become covered with fuzz (Figure 7). This disease is most commonly found infecting F. elastica, although it can also be found frequently on other Ficus species.

\section{Causal agent: Botrytis cinerea}

Factors favoring the disease: Botrytis blight usually occurs during cool, damp periods of the year, especially on cuttings.

Control and treatment: Raise temperatures by turning on the greenhouse heaters and drying the air. Remove infected tissue since spores easily become airborne, rapidly spreading the disease.

A number of fungicides are very effective in controlling botrytis blight (Decree ${ }^{\circledast}$ - fenhexamide, Daconil ${ }^{\circledR}$ - chlorothalonil, Chipco 20619 - iprodione,). These should be used preventatively when disease-conducive conditions occur. 


\section{Corynespora Leaf Spot}

Symptoms: Small to large, reddish leaf spots appear on the youngest mature leaves. Leaf spots expand interveinally. Leaves fall off when infections are severe.

\section{Causal agent: Corynespora cassiicola}

Factors favoring the disease: This disease occurs on both green and variegated forms of $F$. benjamina and F. nitida, but is more severe on the variegated cultivars.

Control and treatment: Keep fertilizer applications at recommended levels, and eliminate overhead water if possible. The same fungicides that are effective for anthracnose control are also effective on Corynespora leaf spot.

\section{Myrothecium Leaf Spot}

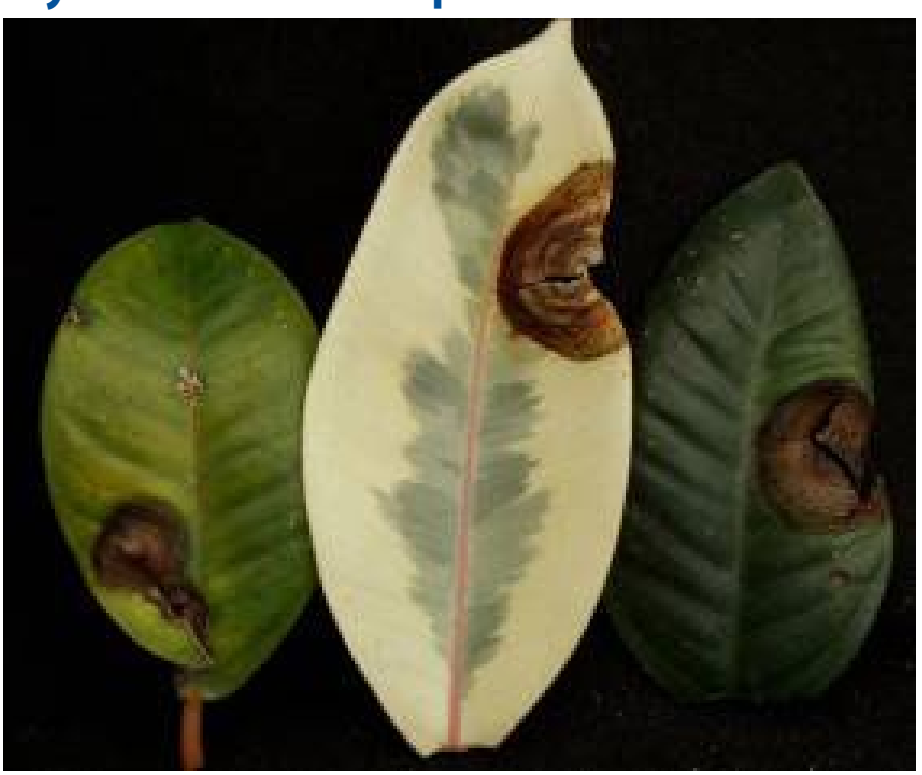

Figure 8. Myrothecium leaf spot on young leaves of Ficus elastica. Note the spores.

Credits: D. J. Norman

Symptoms: Leaves develop circular, dime-sized, brown lesions (Figure 8). Within these lesions, dark black sporecontaining structures (sporodochia) form in concentric rings. Thousands of spores are contained within these structures.

\section{Causal agent: Myrothecium roridum}

Factors favoring the disease: Myrothecium leaf spot is most severe when temperatures are warm and humidity is high.

Control and treatment: Remove infected leaf material to lower the spore concentration in the greenhouse. Minimize wounding. Infections occur primarily through wounds caused by handling.

A number of fungicides are very effective in controlling Myrothecium leaf spot (Insignia ${ }^{\circ}$ - pyraclostrobin, Heritage $^{\circledast}$ - azoxystrobin, Medallion ${ }^{\circledR}$ - fludioxonil). If Myrothecium is present in the propagation area, preventative sprays should be applied to propagation material.

\section{Rhizoctonia Root Rot}

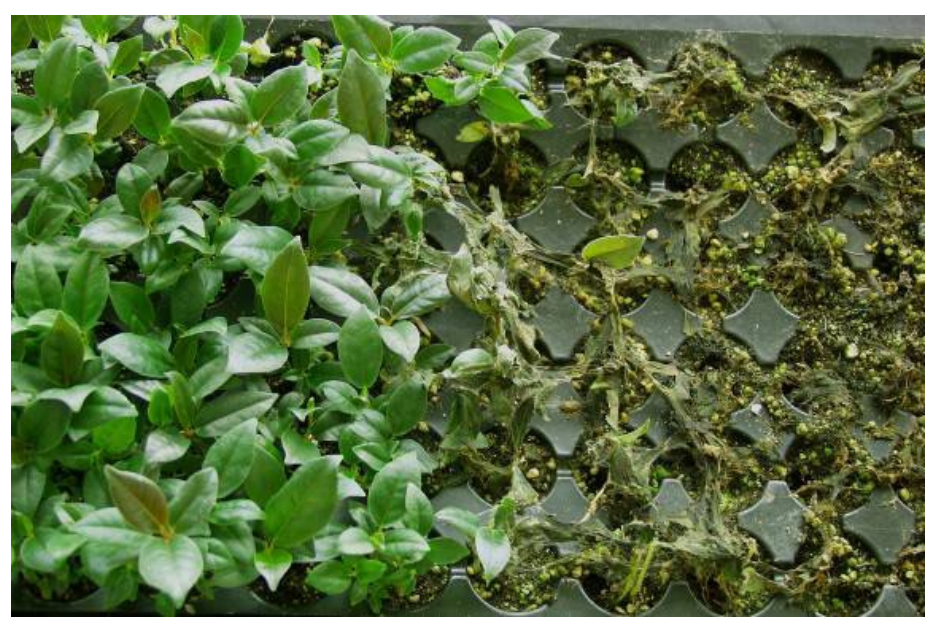

Figure 9. Rhizoctonia root rot of Ficus elastica plugs. Note the matting of necrotic leaves.

Credits: D. J. Norman

Symptoms: Young, tender stems are girdled, become water soaked, and are unable to support the plant's weight. The term "damping-off" is used to describe these classic symptoms (Figure 9).

\section{Causal agent: Rhizoctonia solani}

Factors favoring the disease: Water-saturated soils are conducive to disease development. Rhizoctonia can spread within soil without having a host plant present. It produces constricted small mats of tightly woven mycelia called sclerotia. Irregular in shape, brown in color, and resembling soil particles, Rhizoctonia sclerotia provide a seed-like mechanism for the fungus to survive unfavorable conditions, such as drought or cold weather. These small sclerotia are one of the ways the fungus spreads in nurseries, becoming attached to planting trays and pot surfaces.

Control and treatment: Use disease-free stock plants. Rhizoctonia often gains access to production facilities via infected propagation material. Use well-drained soil mixes, and never store peat moss, sphagnum moss, chips, or media mixes directly on the ground where they can be colonized by the fungus. Except for large container plants, plants 
should be cultivated on raised benches to limit root contact with soil. If potting containers are reused, they should be scrubbed to remove sclerotia and sterilized.

Many fungicides are effective against outbreaks of Rhizoctonia. Examples include Clearys 3336, Fungo (thiophanate methyl), Medallion (fludioxonil), and Contrast (flutolanil).

\section{Southern Blight}

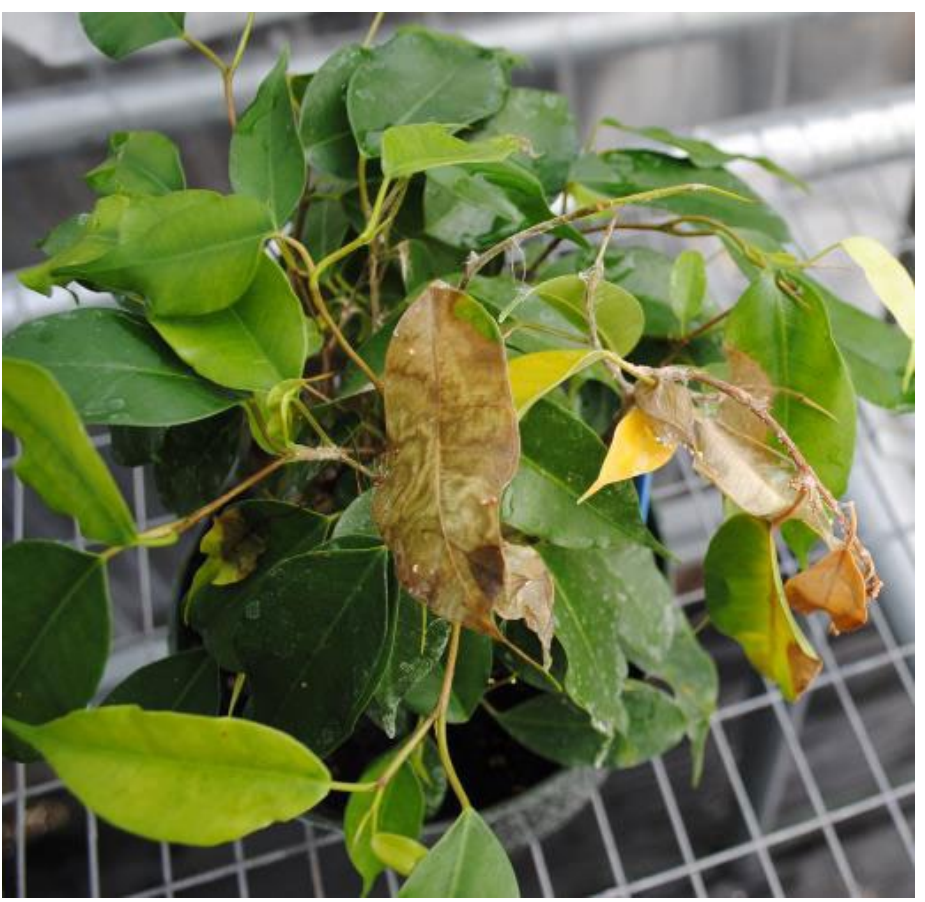

Figure 10. Southern blight on Ficus benjamina.

Credits: D. J. Norman

Symptoms: Sclerotium grows as a white, feathery mycelial mat along the soil surface and on plant parts (Figure 10). Rhizoctonia, on the other hand, always produces brown-colored mycelia. The mycelia eventually form small, circular, brown sclerotia. These are seed-like structures the fungus uses to survive unfavorable environmental conditions, such as dryness. Sclerotia resist penetration by fungicides.

\section{Causal agent: Sclerotium rolfsii}

Factors favoring the disease: Growth of this fungus is especially rapid when soils are wet and weather is hot. Southern blight is common in warm climates, and this pathogen is usually not found in native soils any farther north than Georgia. However, once blight gains access to greenhouse facilities via contaminated soil or infected propagation materials, it can thrive in greenhouse soil anywhere in the United States.
Control and treatment: Use disease-free stock plants to exclude fungal access to production facilities via infected propagation material. Use reliable, commercial, well-drained soil mixes, and never store potting materials directly on the ground where they can be colonized by the fungus. Plants should be cultivated on raised benches to limit root contact with soil. If potting containers are reused, they should be scrubbed and sterilized to remove sclerotia. Plants that have disease symptoms should be discarded, and the rest should be treated with a fungicide drench.

Controlling outbreaks of southern blight with fungicides is difficult. Terraclor (PCNB) and Contrast (flutolanil) have been found effective.

\section{Phytophthora and Pythium}

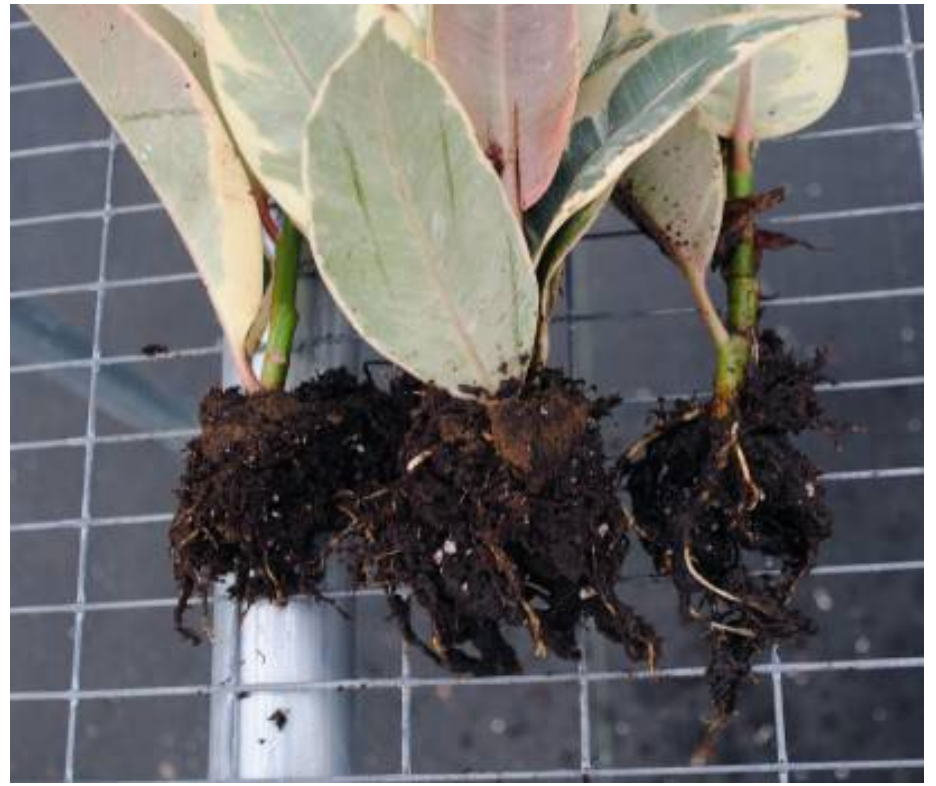

Figure 11. Phytophthora root rot of Ficus elastica cuttings.

Credits: D. J. Norman

Symptoms: Phytophthora and Pythium infections attack the root systems (Figure 11). Plants infected with either of these pathogens exhibit yellowing of leaves, wilting, root dieback, root discoloration, and sloughing of root tissue. Under wet conditions, the foliage may exhibit black to brown lesions. Mycelial growth in the soil or on stems is rarely observed with either Phytophthora or Pythium infections.

Causal agents: Phytophthora and Pythium. Both genera belong to the fungal family Oomycetes. The fungi in this family require water to complete their life cycles. Therefore, these two closely related fungal genera are addressed together. 
Factors favoring the disease: Wet conditions, saturated soils.

Control and treatment: Use well-drained soil mixes. Avoid saturated conditions.

Discards plants that have disease symptoms. Sterilize used pots and trays.

Fungicides such as Subdue ${ }^{\circledast} \operatorname{Maxx}^{\circledast}$ (mefenoxam) and Aliette $^{\circledast}$ (aluminum tris) are effective.

\section{References}

Henley, D. 1991. "An Overview of Ficus for Interior Landscapes." Greenhouse Manager 9 (9): 62, 64-66, 68.

Henley, R. W., and R. T. Poole. 1989. "Evaluation of Selected Ornamental Figs for Interior Use." Proc. Fla. State Hort. Soc. 102: 119-123. 